\title{
Effect of genetic conditions, foliar fertilisation with magnesium and storage on the content of nitrates (V) and (III) in the storage roots in carrot
}

\section{Wpływ uwarunkowań genetycznych, dolistnego dokarmiania magnezem i przechowywania na zawartość azotanów(V) i (III) w korzeniach spichrzowych marchwi}

* Dr inż. Elżbieta Wszelaczyńska, dr inż. Jarosław Pobereżny, Faculty of Agriculture and Biotechnology, Department of Food Technology, University of Technology and Life Sciences in Bydgoszcz, Kordeckiego 20A St., 85225 Bydgoszcz, Poland, e-mail: wszela@utp.edu.pl

\begin{abstract}
** Dr hab. inż. Anna J. Keutgen, prof. nadzw., Faculty of Agriculture and Biotechnology, Department of Food Technology, University of Technology and Life Sciences in Bydgoszcz, Kordeckiego 20A St., 85-225 Bydgoszcz, Poland; Department of Crop Sciences, Division of Vegetables and Ornamentals, University of Natural Resources and Life Sciences, Gregor Mendel Str. 33, 1180 Vienna, Austria
\end{abstract}

Keywords: nitrates, magnesium, carrot, fertilisation, cultivars, storage

Słowa kluczowe: azotany, magnez, marchew, nawożenie, odmiany, przechowywanie

\section{Abstract}

During 2007-2009, studies were undertaken to determine the effect of genetic factors, magnesium fertilisation and storage on the content of nitrates (V) and (III) in carrot roots. After harvest as well as after storage, the cultivar 'Perfekcja' was characterised by the lowest content of $\mathrm{NO}_{3}{ }^{-}$and $\mathrm{NO}_{2}{ }^{-}$, while the greatest amounts were found in cultivar 'Flacoro'. Magnesium was applied in doses of 0,45 and $90 \mathrm{~kg} \mathrm{MgO} \mathrm{ha-1} \mathrm{-} \mathrm{in} \mathrm{the} \mathrm{form} \mathrm{of} 3 \%$ spraying during the vegetation season. The research items were cultivars: 'Berjo', 'Flacoro', 'Karotan', 'Koral' and 'Perfekcja'.

After harvest as well as after storage, the cultivar 'Perfekcja' was characterised by the lowest content of $\mathrm{NO}_{3}^{-}$and $\mathrm{NO}_{2}^{-}$, while the greatest amounts were found in cultivar 'Flacoro'. In this research, each of the applied dose of magnesium fertilisation resulted in a significant increase in the content of nitrates (V) and (III) in carrot roots, but none of the evaluated cultivars did not exceed the allowed amounts. After storage, the content of nitrates $(\mathrm{V})$ decreased for the cultivars 'Berjo', 'Flacoro' and 'Karotan' by $2 \%$, for 'Koral' and 'Perfekcja' by $2.5 \%$, whereas of nitrates (III) for the cultivar 'Berjo' by $1 \%$, 'Karotan' and 'Perfekcja' by $3 \%$ and for 'Flacoro' and 'Koral' by $5 \%$.

(C) IOŚ-PIB

\section{INTRODUCTION}

Carrot (Daucus carota L.) is one of the main vegetable crops grown both for direct consumption and for processing [Gajewski \& Dąbrowska 2007, Czerwińska \& Zgórska 2011]. Due to largescale production and a growing demand, carrots are an essential export goods [Czerwińska \& Zgórska 2011, Filipiak \& Maciejczak 2010, Wszelaczyńska \& Pobereżny 2011]. Carrot is a plant, which has high tendency for the accumulation of nitrates (V) and (III) and their greatest concentration is in the roots [Grudzińska \& Zgórska 2005].

According to the norms, the content of nitrates (V) in carrot should not exceed $400 \mathrm{mg} \cdot \mathrm{kg}^{-1}$ in fresh weight and in the case of carrot allocated to processed foods for children under 3 years of age - $200 \mathrm{mg} \cdot \mathrm{kg}^{-1}$ [Grudzińska \& Zgórska 2005, Murawa et al. 2008, Gajewski et al. 2010, Wrzodak \& Elkner 2010]. The share of nitrates derived from vegetable crops in daily human ratio accounts for $70-90 \%$ [Tamme et al. 2005]. Their negative effect on

\section{Streszczenie}

W latach 2007-2009 podjęto badania w celu określenie wpływu uwarunkowań genetycznych, nawożenia magnezem oraz przechowywania na zawartość azotanów(V) i (III) w korzeniach spichrzowych marchwi. Magnez stosowano w dawkach 0, 45 i $90 \mathrm{~kg}$ $\mathrm{MgO}$ ha $^{-1}-\mathrm{w}$ formie $3 \%$ oprysku w okresie wegetacji. Obiektami badań były odmiany: 'Berjo', 'Flacoro', 'Karotan', 'Koral', 'Perfekcja'.

Najmniejszą zawartością $\mathrm{NO}_{3}^{-}{ }^{-} \mathrm{NO}_{2}^{-}$po zbiorze jak o po przechowywaniu charakteryzowała się odmiana 'Perfekcja' a największą odmiana 'Flacoro'. W prowadzonych badaniach każda z zastosowanych dawek nawożenia magnezem powodowała istotny wzrost zawartości azotanów (V) i (III) w korzeniach marchwi ale żadna z badanych odmian nie przekroczyła dopuszczalnej normy ich zawartości. Po przechowywaniu nastapił spadek zawartości azotanów(V) dla odmian: 'Berjo', 'Flacoro' i 'Karotan' o 2\%, 'Koral' i 'Perfekcja' - 2,5\%, natomiast azotanów (III) dla 'Berjo' o 1\%, 'Karotan' i 'Perfekcja' - 3\% a 'Flacoro' i 'Koral' - 5\%.

the consumer's body comes from the fact that they are getting transformed into toxic nitrates (III), oxidise haemoglobin to methaemoglobin as well as show a destructive effect on vitamin groups A and B as well as carotenoids [Murawa et al. 2008, Marks 2009]. At present, in agriculture there is a search for growing methods, which enrich the material with nutrients and, at the same time, decrease the content of harmful compounds. The quality of storage roots in carrot is cultivar-specific; it also depends on climate-soil conditions, agrotechnical practices as well as the conditions during long-term storage [Seljasen et al. 2001, Santamaria 2005, Tamme et al. 2005, Kona 2006, Ayaz i in. 2007, Gajewski \& Dąbrowska 2007, Murawa et al. 2008, Gajewski et al. 2009b, Karkleliene et al. 2009, Domaradzki et al. 2010, Czerwińska \& Zgórska 2011, Wrona 2012]. Knowing that magnesium participates in the synthesis of carbohydrates, proteins and provitamin A as well as that it is the structural element of chlorophyll [Smoleń \& Sady 2007, 
Wszelaczyńska \& Pobereżny 2011], research has been launched to determine the content of nitrates $(\mathrm{V})$ and $(\mathrm{III})$ in storage roots in carrot depending on the foliar application of magnesium, genetic conditions as well as storage.

\section{MATERIALS AND METHODS}

The research material was derived from field experiments performed in the Kujawy and Pomorze Province over 2007-2009. The experiments were performed on light soil with a slightly acid reaction, a low richness in the available forms of $P$ and $K$ as well as the average richness in $\mathrm{Mg}$. The experiments were set up in a split-plot design in three replicates.

The experiment design included the following factors: evaluation date (after harvest and after storage), cultivars (Berio, Flacoro, Karotan, Koral and Perfekcja), magnesium fertilisation in the form of $16 \%$ sulphate $\left(0,45\right.$ and $\left.90 \mathrm{~kg} \mathrm{MgO} \cdot \mathrm{ha}^{-1}\right)$ with a fixed NPK fertilisation $\left(70 \mathrm{~kg} \mathrm{~N} \mathrm{ha}^{-1}, 80 \mathrm{~kg} \mathrm{P}_{2} \mathrm{O}_{5} \cdot \mathrm{ha}^{-1}\right.$ and $100 \mathrm{~kg}$ $\mathrm{K}_{2} \mathrm{O} \cdot \mathrm{ha}^{-1}$ ). Foliar fertilisation with magnesium was applied twice during the plant growth (July and August) by applying 3\% sulphate solution $\left(300 \mathrm{l} \cdot \mathrm{ha}^{-1}\right)$.

The samples were stored in a traditional heaped pile of earth for 6 months. The scope of this research included determining the contents of nitrates $(\mathrm{V})$ with the ion-selective method using the multifunctional apparatus $\mathrm{CX}-721$ provided by the company Elmetron (Baker \& Thompson 1992). The content of ions $\mathrm{NO}_{2}^{-}$ was determined after its oxidation to $\mathrm{NO}_{3}^{-}$, in an earlier prepared sample of the extract according to the abovementioned method. Statistical analysis was performed for the results of the 3-year research by applying the analysis of variance method to evaluate the significance of the Tukey differences. The coefficients of linear correlation between the characters studied as well as the coefficients of variation were calculated. The daily consumption of nitrates (V) and (III) with the consumption of $55 \mathrm{~g}$ of the storage roots studied were determined.

The publication has been developed with the use of the apparatus purchased as part of project 'Execution of the second stage of the Regional Center of Innovativeness', ' which was co-financed by funds of the European Regional Fund as part of the Regional Operational Programme of the Kujawy and Pomorze Province for 2007-2013.

\section{RESULTS AND DISCUSSION}

The results of the content of nitrates $(V)$ in the roots of five carrot cultivars have been presented in Table 1 . The analysis of variance showed significant differences in the content of nitrates $(\mathrm{V})$ across the cultivars studied. The lowest content of nitrates (V) after harvest and after storage was recorded for 'Perfekcja', 223.87 and $218.90 \mathrm{mg} \cdot \mathrm{kg}^{-1}$, respectively, and the greatest for 'Flacoro' cultivar, 277.23 and $271.58 \mathrm{mg} \cdot \mathrm{kg}^{-1}$ of fresh weight. Different results were reported by Grudzińska and Zgórska [2005] for all the three cultivars; 'Perfekcja' accumulated most nitrates $(\mathrm{V})$ and the content was much higher, namely $464 \mathrm{mg} \cdot \mathrm{kg}^{-1}$ of fresh weight. A high content of nitrates $(\mathrm{V})$ for 'Perfekcja' cultivar was also reported by Wrzodak and Elkner [2010] - $431.6 \mathrm{mg} \cdot \mathrm{kg}^{-1}$ of fresh weight. As reported by Gajewski et al. [2009b], the content of nitrates (V) on average for two cultivars, was $260 \mathrm{mg} \cdot \mathrm{kg}^{-1}$ of fresh weight, and 'Karotan' cultivar showed a greater tendency to the accumulation of nitrates $(\mathrm{V})$ than 'Trafford'.

Gajewski et al. [2009a], on the other hand, report on the contents of nitrates (V) from 132.3 for 'Nebula' to $259.4 \mathrm{mg} \cdot \mathrm{kg}^{-1}$ of fresh weight for 'Mello Yello'. Murawa et al. [2008] as well as Smoleń et al. [2006] recorded the content of nitrates $(\mathrm{V})$ in the storage roots in carrot as follows: 217.9 as well as $49.4 \mathrm{mg} \cdot \mathrm{kg}^{-1}$ of fresh weight, respectively; however, they do not specify the cultivars. Anyszka and Elkner [2007] for carrot-type mini (baby carrots) defined that content as $166.4 \mathrm{mg} \cdot \mathrm{kg}^{-1}$ of fresh weight. Similar results were reported by Dobrzański et al. [2008] - 156.9, Karkleliene et al. [2009] from 157.0 to 341.3 , Sus et al. [2006] - 264.0, Tietze et al. [2007] - 242.5 as well as Ziarati and Arbabi-Bidgoli [2014] $480.1 \mathrm{mg} \cdot \mathrm{kg}^{-1}$ of fresh weight.

None of the cultivars studied exceeded the norm of the content of nitrates (V) (Tables 1 and 2). Different results were recorded by Wrzodak and Elkner [2010] as well as by Ziarati and ArbabiBidgoli [2014] in the research, which reported a considerable ex-

Table 1. Content of nitrates (V) and (III) in [mg $\mathrm{kg}^{-1}$ of fresh weight] and the coefficients of variation CV [\%] depending on genetic conditions and the research date as well as magnesium fertilisation

\begin{tabular}{|c|c|c|c|c|c|c|c|c|c|c|c|}
\hline \multirow{3}{*}{$\begin{array}{c}\text { Research } \\
\text { date } \\
{[\mathrm{A}]}\end{array}$} & \multirow{3}{*}{$\begin{array}{l}\text { Cultivar } \\
\text { [B] }\end{array}$} & \multicolumn{8}{|c|}{$\begin{array}{l}\text { Fertilisation } \mathrm{MgO} \mathrm{kg} \cdot \mathrm{ha}^{-1} \\
{[\mathrm{C}]}\end{array}$} & \multicolumn{2}{|c|}{$\mathrm{CV}[\%]$} \\
\hline & & \multicolumn{4}{|c|}{ Nitrates $(\mathrm{V})^{*}$} & \multicolumn{4}{|c|}{ Nitrates $(\text { III })^{* *}$} & \multirow{2}{*}{$\mathrm{NO}_{3}^{-}$} & \multirow{2}{*}{$\mathrm{NO}_{2}^{-}$} \\
\hline & & 0 & 45 & 90 & Mean & 0 & 45 & 90 & Mean & & \\
\hline \multirow{6}{*}{ 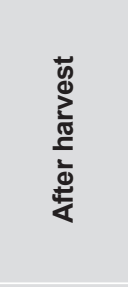 } & Berjo & 225.6 & 229.1 & 233.3 & 229.3 & 1.86 & 1.89 & 1.93 & 1.89 & 1.94 & 2.14 \\
\hline & Flacoro & 264.9 & 275.9 & 290.8 & 277.2 & 2.28 & 2.54 & 2.70 & 2.50 & 4.85 & 8.20 \\
\hline & Karotan & 230.1 & 237.2 & 240.7 & 236.0 & 1.98 & 2.02 & 2.05 & 2.01 & 2.71 & 1.62 \\
\hline & Koral & 238.9 & 245.1 & 252.2 & 245.4 & 2.02 & 2.04 & 2.24 & 2.10 & 2.55 & 5.22 \\
\hline & Perfekcja & 219.3 & 224.0 & 228.3 & 223.9 & 1.77 & 1.84 & 1.86 & 1.82 & 2.19 & 2.52 \\
\hline & Mean & 235.8 & 242.9 & 249.1 & 242.4 & 1.98 & 2.06 & 2.15 & 2.07 & - & - \\
\hline \multirow{6}{*}{ 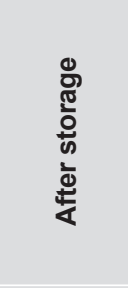 } & Berjo & 220.2 & 227.9 & 226.5 & 224.9 & 1.83 & 1.87 & 1.91 & 1.87 & 2.50 & 2.15 \\
\hline & Flacoro & 260.0 & 271.2 & 283.5 & 271.6 & 2.25 & 2.32 & 2.55 & 2.37 & 4.09 & 6.70 \\
\hline & Karotan & 225.8 & 232.8 & 235.1 & 231.2 & 1.90 & 1.95 & 1.97 & 1.94 & 2.62 & 1.60 \\
\hline & Koral & 230.5 & 241.0 & 247.1 & 239.5 & 1.95 & 2.00 & 2.04 & 2.00 & 3.37 & 3.19 \\
\hline & Perfekcja & 210.2 & 221.3 & 225.2 & 218.9 & 1.69 & 1.81 & 1.82 & 1.77 & 3.65 & 3.96 \\
\hline & Mean & 229.3 & 238.9 & 243.5 & 237.2 & 1.92 & 1.99 & 2.06 & 1.99 & - & - \\
\hline \multicolumn{2}{|c|}{ Mean } & 232.5 & 240.6 & 246.3 & 239.8 & 1.95 & 2.03 & 2.11 & 2.03 & - & - \\
\hline$L S D_{\alpha=0.05}$ & $\begin{array}{l}{ }^{*} A=1.91 \\
B / A=\text { n.s. } \\
A / C=\text { n.s. }\end{array}$ & \multicolumn{2}{|c|}{$\begin{array}{l}B=3.32 \\
A / B=n . s . \\
C / B=7.43\end{array}$} & \multicolumn{2}{|c|}{$\begin{array}{l}C=6.00 \\
C / A=n . s . \\
B / C=8.43\end{array}$} & $\begin{array}{l}{ }^{* *} A=0.021 \\
B / A=\text { n.s. } \\
A / C=0.048\end{array}$ & \multicolumn{2}{|c|}{$\begin{array}{l}B=0.033 \\
A / B=n . s . \\
C / B=0.073\end{array}$} & $\begin{array}{l}C=0.060 \\
C / A=0.066 \\
B / C=0.083\end{array}$ & & \\
\hline
\end{tabular}


Table 2. Daily consumption of harmful nutrients while consuming $55 \mathrm{~g}$ of $\operatorname{carrot}^{*}\left[\mathrm{mg} \cdot\right.$ day $\left.^{-1}\right]$

\begin{tabular}{|c|c|c|c|c|c|c|c|c|c|c|c|c|}
\hline \multirow{3}{*}{ CULTIVAR } & \multicolumn{6}{|c|}{ NITRATES (V) } & \multicolumn{6}{|c|}{ NITRATES (III) } \\
\hline & \multicolumn{3}{|c|}{ After harvest } & \multicolumn{3}{|c|}{ After storage } & \multicolumn{3}{|c|}{ After harvest } & \multicolumn{3}{|c|}{ After storage } \\
\hline & $0^{* *}$ & $45^{* *}$ & $90^{* *}$ & 0 & 45 & 90 & 0 & 45 & 90 & 0 & 45 & 90 \\
\hline BERJO & 12.4 & 12.6 & 12.8 & 12.1 & 12.5 & 12.5 & 0.10 & 0.10 & 0.11 & 0.10 & 0.10 & 0.10 \\
\hline FLACORO & 14.6 & 15.2 & 16.0 & 14.3 & 14.9 & 15.6 & 0.13 & 0.14 & 0.15 & 0.12 & 0.13 & 0.14 \\
\hline KAROTAN & 12.7 & 13.0 & 13.2 & 12.4 & 12.8 & 12.9 & 0.11 & 0.11 & 0.11 & 0.10 & 0.11 & 0.11 \\
\hline KORAL & 13.1 & 13.5 & 13.9 & 12.7 & 13.3 & 13.6 & 0.11 & 0.11 & 0.12 & 0.11 & 0.11 & 0.11 \\
\hline PERFEKCJA & 12.1 & 12.3 & 12.6 & 11.6 & 12.2 & 12.4 & 0.10 & 0.10 & 0.10 & 0.09 & 0.10 & 0.10 \\
\hline MEAN & 13.0 & 13.3 & 13.7 & 12.6 & 13.1 & 13.4 & 0.11 & 0.11 & 0.12 & 0.11 & 0.11 & 0.11 \\
\hline
\end{tabular}

*Mean consumption of fresh and processed carrot (without juices) is $20 \mathrm{~kg} \cdot \mathrm{year}^{-1}$ per person in Poland.

**Magnesium fertilisation rate $\left[\mathrm{kg} \mathrm{MgO} \cdot \mathrm{ha}^{-1}\right]$.

ceeding of the norm of the content even by $80 \mathrm{mg}$, while Moćko and Wackawek [2005] noted that the content of nitrates (V) for 'Perfekcja' exceeded by $31.6 \mathrm{mg}$ and for 'Regulska' by $54.4 \mathrm{mg}$. The results of the content of nitrates (III) have been presented in Table 1. The analysis of variance showed significant differences in the content of nitrates (III) across the cultivars. Similarly, as for nitrates (V) the lowest content of nitrates (III) was noted for 'Perfekcja' and the highest for 'Flacoro' both after harvest and after storage. Such a relationship is confirmed by the calculated positive values of the coefficients of correlation between nitrates $(\mathrm{V})$ and (III) after harvest $\left(r=0.569 ; P_{0.01}\right)$ as well as after storage $\left(r=0.468 ; P_{0.01}\right)$. Murawa et al. [2008], Ziarati and Arbabi-Bidgoli [2014] as well as Ayaz et al. [2007] reported the content of nitrates (III) in carrot as follows: $0.57,1.01$ as well as $0.65 \mathrm{mg} \cdot \mathrm{kg}^{-1}$ of fresh weight; however, they do not specify the cultivars. A very low content of nitrates (III) not exceeding $0.5 \mathrm{mg} \cdot \mathrm{kg}^{-1}$ of fresh weight was recorded by Sus et al. [2006] monitoring the carrot market in Slovenia.

The magnesium fertilisation applied resulted in a significant increase in the content of nitrates (V) and (III) (Table 1). The ap- plicable literature demonstrates that magnesium introduced with fertilisation increases its concentration in the plant intensifying photosynthesis. It also increases the health status of plants by limiting the development of pathogenic bacteria and fertilisation with magnesium sulphate increasing the soil reaction. All those processes decrease the accumulation of nitrates in plants [Smoleń et al. 2010, Waraich et al. 2012]. The opposite result in the present research can be due to an increase in the concentration of sulphate anions in carrot roots supplied with that fertiliser, the excess of which can contribute to the accumulation of nitrates in plants [Smoleń et al. 2006]. An increased content of nitrates in 'Kazan' F1 (however, not exceeding the norm) fertilised with the fertiliser in a sulphate form is also reported by Sady et al. [2005]. After 6 months of storage, there was reported a drop of the content of nitrates (V) for Berjo, Flacoro and Karotanu by $2 \%$ and for Koral and Perfekcja by $2.5 \%$ (Fig. 1), which complies with the results of Gajewski et al. [2010]. Gajewski et al. [2009a], investigating eight cultivars, recorded an average decrease in the content of nitrates (V) accounting for as much as $22 \%$. However, one shall note that in 'Interceptor', 'Nebula' and 'White Satin' after

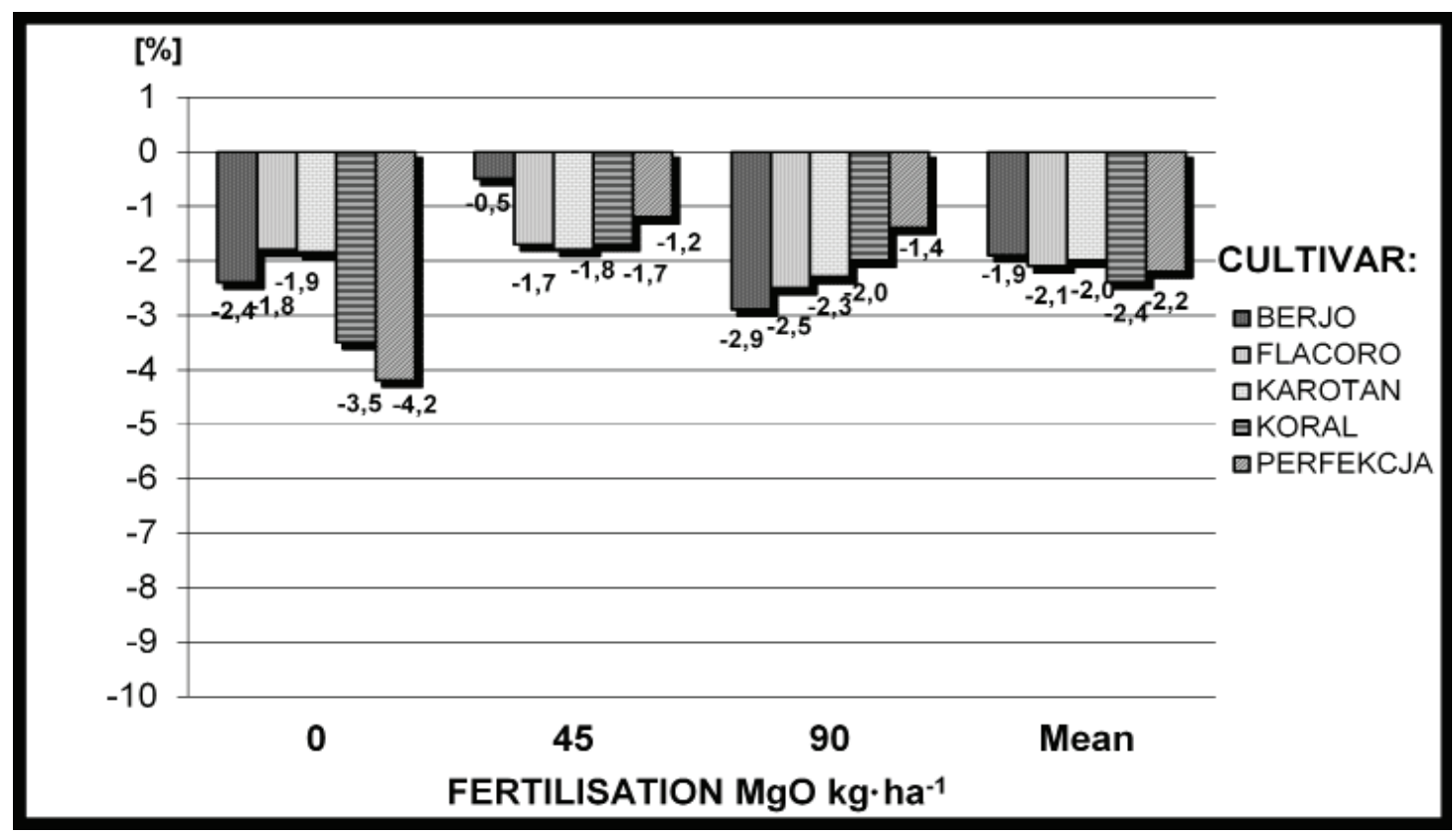

Fig. 1. Percentage losses of the content of nitrates $(\mathrm{V})$ in carrot roots depending on the cultivar, fertilisation and storage period 
storage, there was noted an increase in the concentration of nitrates $(\mathrm{V})$ by $18.9 \%, 0.23 \%$ as well as $1.5 \%$, respectively. Wrona [2012] as well as Czerwińska and Zgórska [2011] claim that during storage, the content of nitrates $(\mathrm{V})$ decreased since they get transformed into nitrates (III). According to many authors, the conditions of storage are one of the key factors affecting the changes in the quality of vegetables [Seljasen et al. 2001, Tietze et al. 2007, Gajewski et al. 2010, Wrona 2010, Wrzodak \& Elkner 2010, Wszelaczyńska \& Pobereżny 2011, Pobereżny et al. 2012]. Wrona [2012] recorded a decrease in the content of nitrates (V) by $13 \%$ and $53 \%$, respectively, in storing carrot both in industrial conditions and in the fridge. Such a high difference could have been due to higher temperature of storage in the fridge than under industrial conditions.

The root storage period also significantly decreased the content of nitrates (III) (Fig. 2) and recording such a result is confirmed by a significantly positive coefficient of correlation between nitrates (V) and (III) after storage $\left(r=0.468 ; P_{0.01}\right)$. The decrease was as follows: 'Berjo' - 1\%, 'Karotan' and 'Perfekcja' - $3 \%$ and for 'Flacoro' and 'Koral' - 5\%. The calculated coefficients of variation for nitrates (V) and (III) (Table 1) show that, as compared with both compounds, 'Flacoro' carrot showed the highest variation and 'Berjo' showed the lowest variation for nitrates $(\mathrm{V})$, while for nitrates (III) - 'Karotan' both after harvest and after storage.
The FAO/WHO Joint Expert Committee on Food [2002] defined the value of the daily consumption from all the sources for nitrates (V) from 0 to 3.7 and for nitrates (III) from 0 to $0.07 \mathrm{mg} \cdot \mathrm{kg}^{-1}$ of the body weight. The values show that the ADI ((Acceptable Daily Intake - by the man of $60 \mathrm{~kg}$ in weight cannot exceed $222 \mathrm{mg}$ of nitrates (V) and $4.2 \mathrm{mg}$ of nitrites (III) [Burt et al. 1993]. With the consumption of $55 \mathrm{~g}$ of the carrot studied, they consume a maximum of $16.0 \mathrm{mg}$ of nitrates (V) and $0.14 \mathrm{mg}$ of nitrates (III) daily, which accounts for $7.2 \%$ and $3.3 \% \mathrm{ADI}$, respectively [Table 2]. Tamme et al. [2005], monitoring the Estonian market, defined the daily consumption of nitrates for adults as $58 \mathrm{mg}$ day 1 for children at the age from 4 to 6 years old $-30 \mathrm{mg}$ and for babies $-7.8 \mathrm{mg}$.

\section{CONCLUSIONS}

The content of nitrates (V) and (III) significantly depended on the genetic conditions; the lowest concentration of the compounds studied was recorded for 'Perfekcja' and the highest for 'Flacoro'. Magnesium fertilisation increased the content of nitrates $(\mathrm{V})$ and (III) in the storage roots in carrot; however, after storage those contents decreased. The cultivars exceeded neither the norm of the content of nitrates in the fresh weight nor the ADI. Due to the toxic effect of nitrogen compounds, a regular monitoring of the content and occurrence of those compounds is necessary.

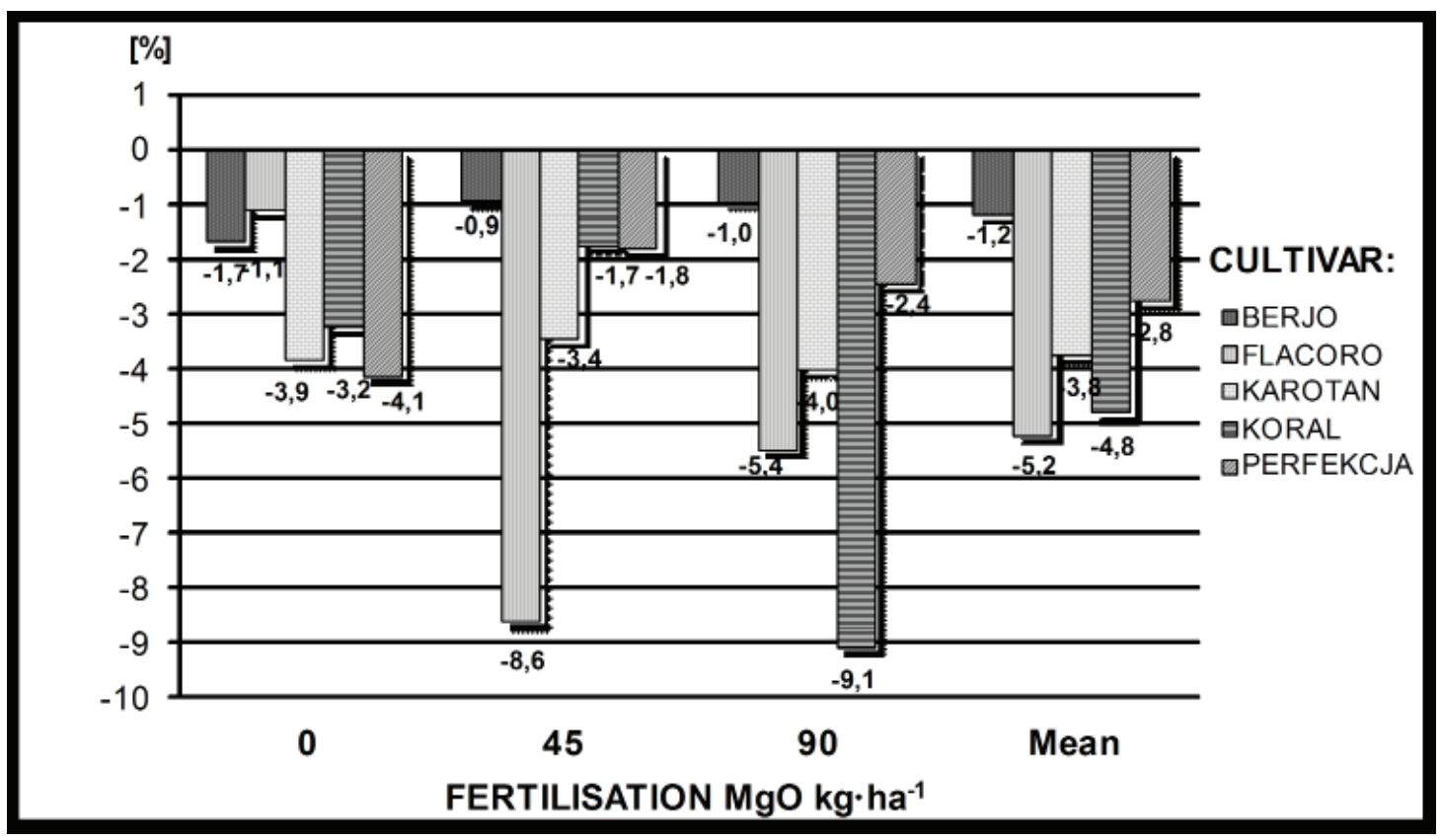

Fig. 2. Percentage losses of the content of nitrates (III) in carrot roots depending on the cultivar, fertilisation and storage period

\section{REFERENCES}

ANYSZKA Z., ELKNER K. 2007. Wpływ niektórych herbicydów na plon i chemiczne cechy jakości marchwi typu baby carrots. Roczniki AR w Poznaniu, CCCLXXXIII: 417-420.

AYAZ A., TOPCU A., YUTTAGUL M. 2007. Survey of nitrate and nitrite levels of fresh vegetables in Turkey. J. Food Technol., 5(2): 177-179.

BAKER W. H., THOMPSON T. L. 1992. Determination of nitrate nitrogen in plant samples by selective ion electrode. Plant Anal. Ref. Proc. for S. US (SCSB \# 368); 23-26.

BURT T. P., HEATHWAITE A. L., TRUDGILL S.T. 1993. Nitrate: Process, pattern and management. Chichester, England, Wiley, 10-28.
DOBRZAŃSKI A., ANYSZKA Z., ELKNER K. 2008. Reakcja marchwi na ekstrakty pochodzenia naturalnego $z$ alg $z$ rodzaju Sargassum AlgaminoPlant i z leonardytu HumiPlant. J. Res. Apel. Agr. Eng. 53(3): 53-58.

CZERWIŃSKA E., ZGÓRSKA K. 2011. Zmiany jakości minimalnie przetworzonej marchwi pakowanej próżniowo w czasie przechowywania. Rocz. Ochr. Środow., T.13: 845-858.

DOMARADZKI P., MALIK A., WÓJCIK W. 2010. Zawartość $\beta$-karotenu i witaminy $\mathrm{C} w$ wybranych produktach $\mathrm{z}$ marchwi. Bromat. Chem. Toksykol. - XLIII., 2; 118-123.

FILIPIAK T., MACIEJCZAK M. 2010. Produkcja warzyw w Polsce i w wybranych krajach UE. Rocz. Nauk. Rol. Seria G, tom 97; 1-11. 
GRUDZIŃSKA M., ZGÓRSKA K. 2005. Effect of preliminary and thermal processing on the content of nitrate in vegetables. Rocznik Ochrony Środowiska, T. 7: 233-241.

GAJEWSKI M., DAC̨BROWSKAA. 2007. Quality characteristics of Carrot cultivars depending to long-term storage. In: Spontaneous and Induced Variation for the Genetic Improvement of Horticultural Products. (P. Nowaczyk, ed.) Univ. Press, Univ. of Technol. And Life Sci. in Bydgoszcz; 95-103.

GAJEWSKI M., SZYMCZAK P., BAJER M. 2009a. The accumulation of chemical compounds in storage roots by carrots of different cultivars during vegetation period. Acta Sci. Pol. Hortorum Cultus 8(4): 69-78.

GAJEWSKI M., WĘGLARZ Z., BAJER M., KUCZKOWSKA A., MAJEWSKI M., WEREDA A. 2009b. Quality of carrots grown for processing as affected by nitrogen fertilization and harvest term. Veg. Crops Res. Biull., 70: 135-144.

GAJEWSKI M., SZYMCZAK P., DANILICENKO H. 2010. Changes of physical and chemical traits of roots of different carrot cultivars under cold store conditions. Veg. Crops Res. Biull., 72; 115-127.

KARKLELIENE R., RADZEVIČIUS A., BOBINA Č. 2009. Productivity and Root-Crop Quality of lithuanian Carnot (Daucus Dativus Rőhl.). Breeder lines. Section, Vol 63, No.1/2, (660/661); 63-65.

KONA J. 2006. Nitrate accumulation in different parts of carrot root during vegetation period. Acta Hort. et Regiotecturae 9: 22-24.

MARKS N. 2009. Zawartość azotanów, azotynów i metali ciężkich w bulwach ziemniaka w zależności od długości okresu przechowywania Inżynieria Rolnicza 1(11): 183-187.

MOĆKO A., WACŁAWEK W. 2005. Ocena zawartości metali ciężkich oraz azotanów(III) i (V) w wybranych gatunkach warzyw ogrodów działkowych miasta Ozimek. Bromat. Chem. Toksykol. 38(1): 41-46.

MURAWA D, BANASZKIEWICZ B., MAJEWSKA E., BŁASZCZUK B., SULIMA J. 2008. Zawartość azotanów (III) i (V) w wybranych gatunkach warzyw i ziemniakach dostępnych w handlu w Olsztynie w latach 2003-2004. Bromat. Chem. Toksykol. XLI(1): 67-71 Nitrate and nitrite content in selected vegetables and potatoes commercially available in Olsztyn.

POBEREŻNY J., WSZELACZYŃSKA E., KEUTGEN A. J. 2012. Yield and chemical content of carrot storage roots depending on foliar fertilization with magnesium and duration of storage. J. Elem. 17(3): 479 - 494.

SADY W., SMOLEŃ S., ROŻEK S. 2005. Effect of differentiated nitrogen fertilization and foliar application on field and biologi- cal quality of carrot crop. Horticulture and Vegetable Growing, 24(3): 273-281.

SANTAMARIA P. 2005. Nitrate in vegetables: toxicity, content, intake and EC regulation. J. Sci. Food Agric. 86(1): 10-17.

SELJASEN R., BENGTSSON G., HOFTUN H., VOGT G. 2001. Sensory and chemical changes in five varieties of carrot in response to mechanical stress and postharvest. J. Sci. Food Agric., 81: 436-447.

SMOLEŃ S., WOJCIECHOWSKA R., SADY W., SZURAA. 2006. Wpływ formy azotu nawozowego i dokarmiania dolistnego na plon i gospodarkę azotowa korzeni spichrzowych marchwi (Daucus Carota L.) Acta Agrophysica 7(3): 721-732.

SMOLEŃ S., SADY W. 2007. Wpływ formy azotu i dokarmiania dolistnego na zawartość karotenoidów, cukrów rozpuszczalnych i związków fenolowych w marchwi. Roczniki AR w Poznaniu, CCCLXXXIII; 619-623.

SMOLEŃ S., SADY W., WIERZBIŃSKA J. 2010. The effect of plant biostimulation with 'Pentakeep V' and nitrogen fertilization on yield, nitrogen metabolism and quality of spinach. Acta Sci. Pol., Hortorum Cultus, 9(1): 25-36.

SUS J., KMECL V., GREGORCIC A. 2006. A survey of nitrate and nitrite content of fruit and vegetables grown in Slovenia during 1996-2002. Food Add. and Contam., 23(4): 385-390.

TAMME T., REINIK M., ROASTO M., JUHKAM K., TENNO T., KIIS A. 2006. Nitrates and nitrites in vegetables and vegetable-based products and their intakes by the Estonian population. Food Addit. Contam. 23: 355-361.

TIETZE M., BURGHADT A., BRĄGIEL P., MAC J. 2007. Zawartość związków azotowych w produktach spożywczych. Annales Universitatis Lublin, Vol. XXV (1): 71-77.

Waraich E. A., Ahmad R., Halim A., Aziz T. 2012. Alleviation of temperature stress by nutrient management in crop plants: a review. J. Soil Sci. Plant Nutr. 12 (2): 221-244.

WRONA P. 2012. Zmiany jakościowe marchwi zachodzące podczas przechowywania. Inżynieria Rolnicza, 2(137) T.2: 337-345.

WRZODAK A., ELKNER K. 2010. Jakość sensoryczna marchwi świeżej i przechowywanej z uprawy ekologicznej. Nowości Warzywnicze T50:93-101.

WSZELACZYŃSKA E., POBEREŻNY J. 2011. Effect of foliar magnesium fertilization and storage on some parameters of the nutritive value of carrot storage roots. J. Elem, Vol. 16(4): 635-649.

ZIARATI P., ARBABI-BIDGOLI S. 2014. Investigation of cooking method on nitrate and nitrite content crops and vegetables and assess the associated health risk. Intern. Journ. of Plant, Anim. and Environ. Sc., 4: 46-52. 